\title{
HOW PERSONS WERE SELECTED FOR INCLUSION
}

The two criteria for inclusion were Frank Brandenburg's top six levels of political prestige, with some modifications, as outlined in The Making of Modern Mexico (Upper Saddle River, NJ: Prentice-Hall, 1964, pp. 158-159), and cross-referencing of biographical data in a minimum of two sources, preferably an official government source as well as a private source. Using Brandenburg's categories, I concentrated on those positions that are stepping-stones to even more influential positions in Mexico.

As Brandenburg makes quite clear in his classic work, his prestige ladder includes only those persons with political prestige; it does not include, for example, business and religious leaders, although some prominent business leaders who have become involved in politics are included. Brandenburg includes the following in his list:

1. The head of the Revolutionary Family. While this person, by Brandenburg's own analysis, may or may not be the president of Mexico, since 1935, every person who has held this position has been president before, during, or after his tenure as head of the Family

2. The president of Mexico

3. Members of the Inner Circle and factional leaders of the Revolution. Persons in this high-prestige category have at one time or another held one of the formal governmental positions making up categories 4, 5, and 6, below. All persons whom Brandenburg classifies as Inner Circle leaders are labeled as such in the biographies, and all of them are included in this directory

4. Cabinet members, including the governor of the Federal District, the military chief of staff, the private secretary to the president, managers of major state industries, and directors of large, federal, semiautonomous agencies, commissions, banks, and boards. An attempt has been made, where information is available, to include all of these individuals in the biographical section

5. Governors of the larger states and the federal territories, ambassadors in prestigious posts, regional strongmen not in the Inner Circle, the two presidential legislative spokespersons in the respective Houses of Congress, military zone commanders, and the official-party (PRI) president

6. Supreme Court justices, senators, assistant secretaries of cabinet ministries, and assistant directors of large state industries, commissions, boards, and dependencies; the secretary-general and sector heads of the official party; leaders of major opposition parties; and the secretaries-general of the major unions. Although senators do not belong in the same categories as undersecretaries, many are included in this book. Entries since the second edition have been selected more carefully based on other career positions, or on their potential for obtaining influential future posts

I have broadened and altered Brandenburg's coverage to include other influentials not falling within his categories. In addition, his placement of certain positions in specific levels is no longer accurate. Included in both the biographical section and the appendixes are two positions which Brandenburg omits entirely: the rectors of the two major public universities in Mexico City, the National Autonomous University of Mexico (UNAM) and the National Polytechnic Institute (IPN). A number of cabinet-level individuals have held these positions, as well as the directorships of the major schools at UNAM (Law, 
Economics, and Medicine), on the way up, between other positions, or after service in the cabinet.

A majority of the individuals who have served as oficial mayor, the third-ranked position in cabinet agencies, have been included. Many of the biographees have held an oficial mayor position immediately before moving up to assistant secretary, as in the case of President Luis Echeverría Álvarez, who was oficial mayor both of public education and of the official party, the PRI, before becoming assistant secretary of government in 1958. Oficiales mayores may well be filling some of the cabinet positions in later administrations, and, therefore, a concentrated effort has been made to include many of them.

In addition to the broad coverage given to the PRI, and despite a critical lack of information, I have included the equivalent top officials from all other influential political parties, most notably, PAN and PRD. This new edition includes several hundred biographies of individuals who have held top posts in parties other than PRI. The only opposition parties listed in the appendixes are the National Action Party (PAN), the Democratic Revolutionary Party (PRD), the Cardenista Front for National Reconstruction (FNCR), the Authentic Party of the Mexican Revolution (PARM), the Mexican Democratic Party (PDM), the Green Party (PVEM), the Convergence Party, and the Popular Socialist Party (PPS). However, presidential candidates and party leaders who have provided opposition to the winning party since 1934 and many precandidates for president within those parties have been included.

The appendixes include a large section on federal deputies, which Brandenburg relegates to level 9. Because of the rubber-stamp function that most Mexicanists attributed to Congress before the democratic transition, there has been a tendency to underrate the position of federal deputy, even though it provides an important training ground for persons moving up the political ladder through elective positions, including that of state governor. I have concentrated on persons who have held a deputyship more than once, or who have held other positions of considerably higher prestige after holding a deputyship. An examination of the biographies included will show that recruitment to Brandenburg's original levels 4 and 5 often occurs because of contacts made in the Chamber of Deputies. Deputies definitely rank higher than ambassadors, ministers, and consuls-general, which Brandenburg placed in a lower category, equated with governors of small and medium-sized states. I also made a special effort to include women in the first two editions, even if they had not achieved quite the same level of political experience as their male counterparts. Those female political pioneers remain in the book, even though it is no longer necessary to use different criteria for female deputies or judges and although they still obtain fewer influential cabinet-level posts.

Other positions included in the appendixes are those which appear most often in the career paths of persons reaching the top four categories, positions which serve as steppingstones to the highest offices in Mexico. For example, with the exception of the ambassador to the United States (a stepping-stone to secretary of foreign relations or secretary of the treasury) and the ambassadorship to the United Kingdom, no specific ambassadorship (including such recently important posts as Japan or the European Economic Community) has consistently had any significance in the career path of public figures. Instead, they have been interim positions for influentials who are "out" or sinecures for persons leaving more influential positions. However, because they have been held repeatedly by high-level government officeholders, ambassadors to the Vatican, Spain, Italy, Japan, Canada, and UNESCO (the United Nations Educational, Scientific and Cultural Organization) have been added to this edition.

Regional strongmen and military zone commanders who have become governors, senators, deputies, or cabinet secretaries have been included. Governors of all states, large and 
small, have been included in the appendixes, and an attempt has been made to include as many as possible in the biographical section. All governors, regardless of state of origin, are playing an increased role in national politics, as appointees to the executive branch and as the presidential candidates of the leading parties since 2000.

The second criterion, the cross-referencing of factual data, dictated that no person be included in the biographical section unless the major governmental positions held were cross-referenced in a minimum of two sources, preferably an official government source as well as a private source. This does not mean that the information contained in the biographies and the appendixes is infallible, since even government sources have proved to be inaccurate on occasion; rather, no biographical data or listings of positions were included unless the information could be substantiated from other sources. Internet searches have facilitated this criterion, allowing me to pursue government documents dating back to the early part of the twentieth century.

As a result of the simple lack of information on some people and positions, more than three hundred people who fitted the political criterion for inclusion in this directory were rejected because of incomplete biographies.

No biography was included if information was missing for three or more of the career categories. For approximately half of the people in this directory, conflicting information exists about their careers, and I have had to judge to the best of my ability which facts are the most valid. 
THIS PAGE INTENTIONALLY LEFT BLANK 